\title{
On the Best Life
}

By Chris Berger

\begin{abstract}
In order to find a thorough treatment of the good life, arguably the subject of political science, we must have recourse to the ancients. Aristotle directly addresses and thematizes the concept of "the good life" in his Nicomachean Ethics, wherein it is suggested that the best possible life for a human being is one that is lived in accordance with a human being's natural function, that is, logos. This paper implements Aristotle's definition of the good life in order to suggest that it presents us with not merely a viable but a superior alternative to the relativistic language of "lifestyles" and "values" that dominates contemporary political theory. This paper will first establish a framework within which the best life for a human being may be understood, then proceed to explain the inadequacy of relativism as a way of conceiving of the best life and the relationship between the best life and the best person. The argument will conclude by making a case for the importance of the best life as a topic worthy of pursuit in both theory and practice.
\end{abstract}

\section{Introduction}

This essay is a restatement of and elaboration upon a previous paper: "The Role of SelfLove in Friendship and the Flourishing Life." It will serve to clarify what I take to be the relationship between the best people and the best life. It will be argued that the ultimate aim of the best life is indeed perfection, regardless of whether or not perfection is actually achievable. The best life is the best not necessarily because it is perfect, but because it attempts to understand and strive for perfection. In order to make this case, it will be argued that one who comes closest to leading the best life will be the best kind of person, in that he is driven by a passionate desire for absolute excellence. In turn, the best person cannot exist without the help of the best friendship, which is what ignites the awareness of and passion for pursuing perfection in people. I will conclude that we ought to desire the best life and to be the best people.

\section{How can we think of the Best Life?}

Aristotle's arguments in the Nicomachean Ethics will be used to suggest away in which the best life may be thought about. In the tenth and final book of this work, Aristotle says that the contemplative life is the best. ${ }^{1} \quad$ He claims that this is the case because the activity of contemplation is the activity most in accordance with what is highest in human beings, i.e. reason or logos. I have argued in my previous essay that the philosopher, in leading the life of contemplation, is the best person and that he leads the best life, as he leads a life of activity in accordance with reason. In living in accordance with what is highest in human beings, he is the best person, and as this activity comes closest to grasping the divine and the eternal, it is the best life. However, it has become apparent that to leave a statement on the best life and the best person at this results in ambiguity: is the best life the life of sitting in an armchair and "thinking"? Surely this is not the case. Aristotle himself points out that only a god could engage

\footnotetext{
${ }^{1}$ Aristotle Nicomachean Ethics 1177a17
} 
in contemplation to the exclusion of all other activities. ${ }^{2}$ It hardly needs to be said that we are not gods.

As an example (and this is not to say that Aristotle would necessarily have put it this way) of an alternative way to think about how, say, contemplation fits in to the best life, consider for the sake of argument the tripartite soul, ${ }^{3}$ composed of appetite (epithumea), spirit (thumos), and reason $(\log o s)$. The philosopher's soul is not composed purely of reason; reason is simply situated above or "in charge" of spirit and appetite, just as the warrior places spiritedness at the helm with reason and appetite in its service. In the contest of book ten of the Nicomachean Ethics, this way of thinking about the best life seems incompatible at first; Aristotle mentions nothing else but contemplation in the best life. However, what are we to make of the book devoted to justice, or the full three books devoted to the moral virtues? The first inference we are to draw is that the moral virtues (and so practical wisdom) are indispensable in the good life, if we take the Nicomachean Ethics to be an enquiry into the good life. If this is the case, there is no reason to presume that a life of contemplation excludes morally virtuous activity when it is called for.

Other commentators, such as Aristide Tessitore, address the problem of the dual account of the good life that Aristotle seems to give. In "Aristotle's Ambiguous Account of the Best Life", Tessitore suggests that Aristotle is addressing two audiences simultaneously: "gentlemen" and "potential philosophers." Although Tessitore's solution to the problem of these two seemingly conflicting versions of the good life is in many ways quite "Platonic" (and arguably unfaithful to Aristotle), his thesis should not be dismissed out of hand. Indeed, the structure and layout of the Nicomachean Ethics supports such an interpretation: Aristotle begins by addressing the difficulties in thinking of (let alone achieving) the best life; he then defines and elaborates upon the moral virtues, building then to justice, the intellectual virtues, pleasure, friendship, and finally, the happiest life. When broken down, the Nicomachean Ethics does indeed address itself to the so-called "gentlemen" (for convenience's sake: politically or publicly active and responsible individuals) first, and then progresses in a hierarchical manner to cap off the absolute best achievable life with philosophic wisdom and contemplation. The gentleman is not without intellect, and the philosopher is not without the non-rational components of a human being; rather, their components are simply ordered differently. The gentleman prioritizes and develops the moral virtues so as to prepare himself for the public life; however, his life cannot be the best, as he does not develop what is highest in human beings. Conversely, the philosopher does not prioritize the moral virtues, but they do not pertain to the highest things. Aristotle's reason for claiming that the contemplative life is the happiest is that it includes the development of reason, not that it is devoid of any of the non-rational components.

We must think of the best life in terms of an amalgam of all the components of human life; what makes the best life the best is not necessarily what it possesses that others lack (though some lesser lives may indeed lack something), but how the components of that life are organized in relation to one another. Aristotle may divide these components into broad categories of morality and intellect, and subdivide these into various virtues, or we may divide them into

\footnotetext{
${ }^{2}$ Ibid 1177b26-30

${ }^{3}$ See: Plato Republic Book IV

${ }^{4}$ Aristide Tessitore "Aristotle's Ambiguous Account of the Best Life" in Polity, Vol. 25, No. 2 (Winter, 1992), 201.
} 
categories of, say, passion, reason, and so on. Or, we may not feel the need to categorize them at all; what matters and what we all will likely agree upon is that a life is composed of various "parts". It will be comprised of many things, including friendship, a pursuit of "interests", "fun", a sense of accomplishment, et cetera. The best life will contain all of these (and this list does not come close to being exhaustive), and it will be defined as being the "best" according to how all of these parts are ranked, prioritized, and developed.

\section{Why Relativism is Unhelpful (and Wrong)}

Before proceeding, it is important to address any controversies that may be provoked by the use of the word "best" in association with life. It may be argued that the best life for one person will not be the best life for another, and such an argument will undoubtedly cite Aristotle's discussion of the moral virtues and practical wisdom. In addressing these topics Aristotle makes clear that the practical intellect (practical wisdom) aims at an end and is concerned with decisions and choices of individuals in specific instances, ${ }^{5}$ and that behaviour in accordance with practical wisdom is morally virtuous. ${ }^{6}$ It is for this reason that the famous mean is not merely situated dead centre between two extremes (such as, say, cowardice and rashness) but is dependent upon the situation. The mean with regard to fear is courage; a courageous person does not simply sit on the fence between always being afraid and being fearless, but is afraid and unafraid of those things of which he should be afraid or unafraid, and handles his feeling of fear in a proper manner when it does arise. This argument of Aristotle's could be used to affirm that all action and hence the good life is relative with respect to each individual and situation.

However, this argument misses the point of Aristotle's mean, likely by confusing morally virtuous actions with actually being morally virtuous. It is indeed true that different people will experience to varying degrees situations in which they are required to act in a morally virtuous manner. To continue with the example of courage, few people are ever required in their lives to make the decision to rescue a child from a burning building. Surely, the mere fact that a specific individual is never "given" the "opportunity" to demonstrate his courage by helping someone out of a burning building does not mean that he is cowardly. Relativism, however, mistakes the particular action for the universal virtue itself. A relativistic argument would state that courage is relative to the individual and the life that he leads, and that since some people are never called upon to act courageously while others are means that courage is not plainly required for a good life or in order to be a good person. What this argument fails to acknowledge, however, is that it is courage itself that is present in the good person, and one need not constantly experience traumatic events in order to be courageous. A courageous person may be one who simply controls the passion of fear so as not to experience it irrationally; such a person may very well find, say, spiders or heights to be somewhat unpleasant, but in actually achieving the mean with regard to fear will not be enslaved by irrational fear. The relativist argument is too particularistic, and ignores the fact that, though courage may be manifested in particular actions, there is nonetheless such a thing as courage qua courage, and that the good and happy person will exhibit it universally.

\footnotetext{
${ }^{5}$ Aristotle Nicomachean Ethics $1139 \mathrm{a} 30$ - 1139b5; 1142a20-25

${ }^{6}$ Ibid $1144 \mathrm{~b} 30-32$
} 
To broaden the scope of this argument, we may now consider the best life as such. I have suggested that the best life is such because of how its components are ordered. The relativist argument would undoubtedly accept the suggestion that a life may be ordered in any number of ways, but it would diverge on the claim that there is a single best way in which a life could be ordered. The discrepancy likely lies in the "components" themselves; it may be argued that some people prefer a life of action or public involvement, while others prefer contemplation, et cetera. The best life would then seem to be reducible to opinion and preferences based upon opinion. The argument could be made that there are many different ways of ordering the parts of one's life, and that many (indeed, most) people structure their lives differently, which is undeniably true. However, this argument by no means succeeds in making the case that there is no single best life; it would be akin to saying that there are many different opinions regarding what truth is, hence there is no truth. At this point we should ask the relativist whether that is in fact true. The relativist argument is therefore not helpful in thinking about the best life; it merely provides a convenient way out of confronting this difficult question directly. There is nothing (besides basic logic, of course) stopping anyone from dismissing the best life as relative by positing that any way of life, so long as it makes one "happy", is equally as valid as any other. However, it is precisely those who give up the challenge so easily that will never achieve the best life; they may very well lead quite pleasant lives, but they will not be the best. Attaining the best life is possible only for the person who realizes the logical contradictions inherent in relativism, and so refuses to settle for the mediocrity of: "you do what you like, I will do what I like; no one way is better than any other." Relativism idolizes the ordinary and the mundane; Aristotle urges us to look to the extraordinary instead. This is the kind of person, the extraordinary person, whom we should try to understand and emulate.

\section{Why the Best Life Presupposes the Best Person}

The Nicomachean Ethics, I maintain, is addressed to those who are concerned with the extraordinary. Tessitore is correct to stress the significance of the fact that Aristotle addresses the moral virtues first. Books two through four are of interest primarily to "decent but not necessarily philosophic students." It is these "decent" people, unconcerned with individual excellence in the absolute and "perfect" sense, who are to be made into competent public figures in these books on moral virtue. As the Nicomachean Ethics progresses from the moral virtues to the life of contemplation, these "gentlemen" are left satisfied with their practical virtue and thus non-hostile toward the contemplative life. Those not equipped to tackle "Happiness" (associated with the best life) can at least be more-or-less "happy." As Aristotle says, those who are to benefit by practicing the political and moral virtues must be experienced and so already convinced of the goodness of virtue. ${ }^{8}$ Aristotle certainly seems to assume that whoever is reading his work has been previously convinced of virtue's desirability. The other class is that of those who desire something beyond virtue simply; book ten would seem to be addressed to these. However, there certainly does seem to be a remaining third class of people. We seem to be left with at least the young, or those who are not convinced of either the desirability of virtue (because they are inexperienced) or that of the contemplative life (because they are not motivated

\footnotetext{
${ }^{7}$ Aristide Tessitore "Aristotle's Ambiguous Account of the Best Life" in Polity, Vol. 25, No. 2 (Winter, 1992), 203.

${ }^{8}$ Aristotle Nicomachean Ethics 1094b28-1095a5
} 
by the extraordinary). Presumably these people Aristotle would regard as experiencing the most basic forms of desire, and as he does not appear to address them anywhere in the work, it is possible that he either does not have any regard for them at all, or believes that no call to virtue or excellence will have an effect upon them. He is not wrong.

Tellingly, Aristotle does not even address the intellectual virtues until both justice and the moral virtues have been covered. Once discussing the intellectual virtues, it is notable that practical wisdom, which is dependent upon moral virtue, is featured prominently. Nonetheless, Aristotle says that "it would be thought strange if practical wisdom, being inferior to philosophic wisdom, is to be put in authority over it," making clear that, when philosophic wisdom is present, it ultimately governs practical wisdom and the moral virtues to which practical wisdom pertains. Soon after, Aristotle then mentions the indivisibility of the virtues in the flourishing life, ${ }^{10}$ and reiterates that if one possesses practical wisdom, one will by necessity possess the natural virtues. ${ }^{11}$ This passage is vital for coming to grips with a conception of what the best person would look like, in that it lays out more concretely than anywhere else in the work the relation of the parts of a flourishing human being to one another. This passage is concluded with the statement that "it is not the case that practical judgment [practical wisdom] is in authority over [philosophic] wisdom or over the better part of the soul, just as the medical art is not in authority over health; for medicine does not make use of health, but sees how it may come about, and then it gives orders for the sake of health, not to health." ${ }^{\prime 2}$ In general, the moral virtues are open to anyone, provided they gain experience (as these virtues are practiced). The development of full moral virtue results in one who is practically wise. Practical wisdom is for the sake of philosophic wisdom. Since it pertains to what is superior in us, that is, reason, philosophic wisdom is the key to completing a somewhat happy life, making it into a yet-happier and more flourishing one (flourishing understood in the case of human beings as the good use of reason).

\section{Why the Best Life is Worth Working For}

Two notes of clarification: first, it is not said by Aristotle, and at any rate may not be the case, that philosophic wisdom requires practical wisdom, merely that practical wisdom when present is in service of philosophic wisdom; second, though the best life in theory would follow from all of this as being the good use of reason (as opposed to the development of it), we must remember that even Aristotle stresses that only gods contemplate purely and exclusively. Regarding first point, we cannot conclude that the person leading the contemplative life need be a "gentleman" or a public figure at one point. These two audiences of the work likely have differing passions and motivations that are molded by their upbringing (which is why Aristotle is so concerned with upbringing; it shapes one's passions). As for the second point, regardless of whether this is the case for Aristotle or not, I suggest that the contemplative life as human beings are able to achieve it is not the possession of absolute knowledge or wisdom, but the philosophic life in the sense of actively seeking and striving for wisdom. Perfection is not possible, but the life in service of what is best in us, that is in service of what makes us human, is a life with an

\footnotetext{
${ }^{9}$ Ibid $1143 \mathrm{~b} 33-34$

${ }^{10}$ Ibid 1144 b32-35

${ }^{11}$ Ibid 1145a1-2

${ }^{12}$ Ibid $1145 \mathrm{a} 6-9$
} 
eye toward what is probably unattainable but the pursuit of which can only make us better for the effort. Simply because perfection is seemingly beyond human beings does not mean that it is not worth working for.

This is why friendship (as Aristotle says explicitly) and eroticism (as Aristotle says only implicitly) are of such vital importance. I have said in my previous essay that the best friendships involve the best people, and I stand by that claim. I clarify it by adding that it is the best type of friendship that creates the best people; those erotic enough to be driven by the passion for perfection and human excellence undoubtedly make the best of friends when they happen upon one another. Others may have very meaningful, pleasant, and lasting friendships, but there is something about the friendship between two people of the type here described that makes it qualitatively and not merely quantitatively different. These two friends do not attain more pleasure by being in each others' company; rather they experience a better and profounder pleasure by drawing out of each other the self-realization that they do not want to submit to and settle for mediocrity. This is why people leading the philosophic life still need friends. Indeed, they have an even more dire need of friendship. Aristotle recognizes that a friend of the best kind is a second self - a mirror that admits of a greater sense of self-understanding. This mirror is what awakens the awareness of one's erotic, passionate desire to know, to probe the questions and limits of human potential.

Therefore a dismissal of the attempt to vindicate the life of human reason (that which is superior in us, that makes us human) on the grounds that it is "unrealistic" or "elitist" is of no help at all. Relativist claims can only serve to enforce a false, shallow, and empty "satisfaction" with the "how we are." They cannot aspire to the "what we could be." Of course friendship, humour, love, and any manner of intrinsically vital components of the human being are important for the flourishing life; indeed, the life of contemplation, the best life, requires them. To separate and categorize contemplation, friendship, love, fun, and adventure into their own separate types of "lives" is to miss the point of what the best life is. It is the life of aspiring to perfection, and it can only be lived by the best person (who is one who passionately desires perfection). Many other lives may include some or even all of what was just mentioned, but if they leave out what is best in us as human beings, they fail to satisfy the desire for perfection. The relativist tendency to put all lives on a level is sterile and unerotic. We ought to deserve better than a common denominator or a "world-view" in which all is equal to all "as long as it makes us "happy", but we can only deserve better if we actively desire and work for what is better. Happiness is otherwise far less satisfying than it has the potential to be. Aristotle had a good point: the contemplative life, being perfect, is probably unattainable, but it can be approximated by the philosophic life (the life of erotic striving). Only the best and most erotic individuals are up for it, and they are up for it because they have the best and most erotic friendships. Human beings qua human beings are characterized by the possession of reason, and so the best human life simply must regard reason as superior.

\section{Conclusion}

In this essay I have attempted to clarify my previous claim that there is a best life, and that it is livable only by the best person. I have stood by that claim, and have sought to 
demonstrate more clearly what the best life is, and why it is the best person who is equipped to live it. The best life is the life of striving for perfection, and perfection is not relative. The best person is the best because he refuses to submit to the sterility and emptiness of relativism; he wants more. It is friendship that causes this desire to bloom. The best life is the life of perfecting reason, but the perfection of reason requires all the other components of one's life to be arranged well. It does not exclude love, friendship, and passion, but is dependent upon them. There is a best life, and it is worth the effort. 


\section{Bibliography}

Aristotle. Nicomachean Ethics. Translated by Joe Sachs. Newburyport, MA: Focus Publishing, 2002.

Plato. Republic. Translated by Allan Bloom. New York: Basic Books, 1991.

Tessitore, Aristide. "Aristotle's Ambiguous Account of the Best Life" in Polity, Vol. 25, No. 2 (Winter, 1992). 